\title{
DIE PERSEPSIES EN ROL VAN MAATSKAPLIKE WERKERS TEN OPSIGTE VAN MENSEHANDEL
}

\section{Yolanda Mynhardt, Herman Strydom}

\section{INLEIDING}

Maatskaplike werkers behoort 'n belangrike rol te speel in dienslewering aan slagoffers van mensehandel en om hulle in aanraking te bring met die nodige hulpbronne. In hierdie ondersoek is die kennis en persepsies van maatskaplike werkers van verskillende organisasies ingewin ten einde vas te stel wat maatskaplike werkers se persepsies oor mensehandel is en wat hulle as hul rol in die bekamping van mensehandel beskou. In hierdie verkennende studie word die probleemstelling eerstens aangebied, waarna die navorsingsvrae, doelstelling en doelwitte ter sprake kom. Die benutte navorsingsmetodologie binne die kwalitatiewe paradigma word hierna bespreek voordat die bevindinge aangebied word. Die bevindinge word in 'n aantal temas en sub-temas verwoord, waarna die bespreking van die bevindinge, die aanbevelings en 'n samevatting ter sprake kom.

\section{PROBLEEMSTELLING}

Mensehandel word beskou as die vinnig uitbreidende kriminele bedryf in die wêreld en genereer 'n jaarlikse profyt van tot 7 biljoen dollar wat die handeldryf met mense 'n winsgewende bedryf maak (International Rescue Committee, 2003:1; Joshi, 2002:18; Lima, 2007:7). Jaarliks word ten minste 4 miljoen mense die slagoffers van mensehandel, oor of binne nasionale grense, wat met die grootste onmenslikheid behandel word (Joshi, 2002:18). Mensehandel vind nie net oor landsgrense plaas nie, maar ook binne een land van landelike na stedelike gebiede (International Organization for Migration, 2009a:2). Die getalle in mensehandel is egter net skattings, wat meebring dat die ware voorkoms van mensehandel onbekend bly (Loretz, 2004:1). Die werklike omvang van mensehandel is onseker, juis omdat dit hoofsaaklik ondergronds bedryf word.

Mensehandel het sy ontstaan gehad as gevolg van die veranderinge wat globalisering gebring het. Die ontwikkeling van industrialisering het drastiese veranderinge in mense se lewens tot gevolg gehad (Joshi, 2002:19). Die geskiedenis dui op talle voorbeelde van samelewings waar slawerny en uitbuiting van mense as aanvaarbaar beskou is, en gewoonlik was dit vroue en kinders wat onderworpe was aan mensehandel en spesifiek om as prostitute te werk (Loretz, 2004:9). Die geskiedenis van mensehandel dateer uit die Romeinse era toe slawe op plantasies gewerk het, en tydens die vestiging van die Verenigde State van Amerika (Michael, 2000:5). Hierdie ondergrondse industrie, met sy komplekse netwerke, wat spesifiek voortgedryf word deur sosiale, ekonomiese, kulturele, politieke en globaliseringsfaktore, is nog nie voldoende deur huidige navorsing ondersoek. Daar bestaan dus 'n groot leemte ten opsigte van kennis hieroor betref. Meer publikasies behoort die lig te sien oor die toenemende nasionale en 
internasionale bekommernis oor mensehandel en die wyses om dit te voorkom en te behandel (International Organization for Migration, 2005:7).

Mensehandel in Suid-Afrika is 'n realiteit (Del Carmen Balderas, 2006:3) omdat die Suid-Afrikaanse Bruto Buitelandse Produk plus-minus vier maal groter is as dié van sy omliggende buurstate. Suid-Afrika dien dus as 'n aantrekkingskrag vir die vervoer van mense en 'n bestemming vir mans, vroue en kinders wat slagoffers van mensehandel is met die doel om hierdie individue uit te buit deur middel van gedwonge arbeid, op die seksuele gebied en die handeldryf met organe (United Nations Educational, Scientific and Cultural Organization, 2007:10-11). Tradisionele migrasiepatrone van omliggende buurstate na Suid-Afrika, soos natuurlike en mensgemakte rampe, mense wat in SuidAfrika kom werk soek, kinders wat gestuur word om in beter omstandighede groot te word en verslapte grensprosedures, dra by tot mensehandel in Suid-Afrika.

Die volgende navorsingsvraag word dus gestel:

Wat is die aard en bewustheid van mensehandel en wat kan as die taak van maatskaplike werk in mensehandel beskou word?

\section{DOELSTELLING EN DOELWITTE}

Die doelstelling van hierdie ondersoek word soos volg aangedui:

Om die aard en bewustheid van mensehandel en die taak van maatskaplike werk in mensehandel te verken.

Die volgende twee doelwitte word hieruit geformuleer:

- Om die aard en bewustheid van mensehandel te omlyn; en

- Om die taak van maatskaplike werk ten opsigte van mensehandel te verken.

\section{NAVORSINGSMETODOLOGIE}

Die kwalitatiewe navorsingsbenadering is in hierdie studie benut en behels deelnemers se sienings van betekenisse, ervarings en persepsies rakende ' $n$ bepaalde aangeleentheid (De Vos et al., 2011:65). Daar is dus gepoog om 'n verkennende studie te doen wat 'n relatief nuwe onderwerp dek soos in hierdie geval, mensehandel (Babbie \& Mouton, 2010:79). Ooreenkomstig die kwalitatiewe benadering is daar van doelgerigte steekproeftrekking binne nie-waarskynlikheid-seleksie gebruik gemaak (Engel \& Schutt, 2010:96). Data is ingesamel totdat data-versadiging bereik is en is 6 maatskaplike werkers in die Potchefstroom area uiteindelik as deelnemers aan persoonlike onderhoude en 'n fokusgroep (Corby, 2006:147-148; Monette et al., 2011:191-193) betrek.

Hierdie maatskaplike werkers kan as verteenwoordigend van die area beskou word en is verteenwoordigers van die Departement Maatskaplike Ontwikkeling en NieRegeringsorganisasies by die ondersoek betrek ten einde 'n ryke spektrum van ervaring van die verskynsel te kon kry. Drie van die deelnemers het eerstehandse kennis van orgaanhandel gehad, terwyl die ander nie direk met die verskynsel van mensehandel te doen gehad nie, maar wel hul kennis opgedoen het deur die bywoning van kursusse en eie navorsing wat oor die onderwerp onderneem is. 
Semi-gestruktureerde onderhoude (Mitchell \& Jolley, 2010:277) is met deelnemers gevoer met behulp waarvan die navorsers gepoog het om 'n gedetailleerde idee te verkry van deelnemers se oortuigings of persepsies rakende mensehandel. $\mathrm{Na}$ afhandeling van die semi-gestruktureerde onderhoude is 'n fokusgroep met die deelnemers gehou ten einde die gedeelde ervaring, interaksie en bespreking daarvan, wat 'n fokusgroep aan navorsers bied, te verkry.

Alle toepaslike etiese aspekte vir hierdie ondersoek is in die ondersoek verdiskonteer. Ingeligte toestemming is van deelnemers verkry met betrekking tot die doel van die ondersoek en die prosedures wat tydens die ondersoek gevolg sal word. Deelnemers kon hulle ook te enige tyd aan die ondersoek onttrek. Die moontlikheid van misleiding is deeglik in ag geneem, asook die versekering van privaatheid, anonimiteit en konfidensialiteit (Grinnell \& Unrau, 2008:44-57). Na die insameling van die data is dit geanaliseer deur van Tesch se benadering gebruik te maak (De Vos et al., 1998:343-344) wat behels dat die navorsers eerstens 'n geheelbeeld van die data moet verkry, waarna een onderhoud se notas deurgelees word en verdere aantekeninge notas daaroor gemaak word en dan sekere unieke temas geïdentifiseer word wat die navorsers weer na die data terug neem.

Die gehalte van die data is tydens die ondersoek deeglik in gedagte gehou en daar is veral gefokus op die vertrouenswaardigheid, betroubaarheid en bevestigbaarheid van die ingesamelde data (De Vos et al., 2011:419-421; Thyer, 2010:421-422). Vertrouenswaardigheid is bereik deur bepaalde grense aan die ondersoek te stel, langdurige betrokkenheid met deelnemers te onderhou en triangulering van data tussen die onderhoudvoering en die fokusgroep te bewerkstellig. Betroubaarheid is verkry deur seker te maak dat die navorsingsproses logies verloop en data regdeur die proses goed gedokumenteer is. Veldnotas wat aanvanklik gemaak is, is direk na elke sessie volledig in verslagvorm weergegee ten einde die navorsers se eie houdings en standpunte ondergeskik aan die ingesamelde data te stel. Bevestigbaarheid het behels dat die navorsers deurgaans objektief met die data gehandel het en dit laat bevestig het deur 'n medenavorser.

\section{BEVINDINGE}

Die resultate word ontleed aan die hand van die volgende bevindings wat in temas en sub-temas weergegee word. Die temas word opeenvolgend aangebied en word in drie hoofgroepe aangebied, naamlik die temas wat oor die mensehandelaar self handel, die temas rakende die slagoffer en die temas wat oor die taak van die maatskaplike werker handel. Verskillende sub-temas word in elk van die drie temas aangebied.

\section{Mensehandel en mensehandelaar}

Onder hierdie tema word die volgende vier sub-temas behandel, naamlik die begrip mensehandel, oorsake van mensehandel, kenmerke van mensehandelaars en die werwing van slagoffers. 


\section{Die begrip "mensehandel"}

Die volgende aanhalings van deelnemers kan as verteenwoordigend van die verskillende standpunte oor die begrip "mensehandel" beskou word.

"Die begrip behels die werwing van persone in een land of streek en die vervoer, oordrag en ontvangs van persone in 'n ander land of streek."

"Dreigemente, dwang, valse beloftes, ontvoering, bedrog en misleiding speel altyd ' $\mathrm{n}$ rol in mensehandel."

"Uitbuiting is altyd teenwoordig in gevalle van mensehandel, hetsy dit finansieel of seksueel van aard is."

"Prostitution, forced labour and other forms of exploitation can be found."

"Mensehandel is moderne slawerny en behels die uitbuiting van 'n individu vir die geldelike gewin van die mensehandelaar.

"Daar bestaan verskillende soorte mensehandel waaronder kinderarbeid en prostitusie onderskei kan word."

"Dwelmhandel kan dikwels met mensehandel in verband gebring word."

"The trading in human organs can also be regarded as a form of human trafficking."

Uit die voorafgaande standpunte is dit dus duidelik dat dwang, dreigemente, valse beloftes, ontvoering, misleiding en die ontkenning van die individu se vryheid 'n rol by mensehandel speel (Dunn, 2003:17-20; Salett, 2006:1). Uitbuiting van mense is altyd teenwoordig en word as moderne slawerny beskou waarby geldelike gewin altyd 'n rol speel (Adult and Family Services, s.a.). Prostitusie, gedwonge arbeid en selfs die verwydering van organe word beskou as sommige van die vorme wat mensehandel kan aanneem (Blum, 2008:12; Dunn, 2003:15; Michael, 2000:3; United Nations Educational, Scientific and Cultural Organization, 2007:21). Volgens Loretz (2004:18-19) word mense "gestoot" uit arm lande waar ekonomiese geleenthede tekort skiet en "getrek" na lande met 'n hoër vlak van ekonomiese vooruitsig. Mensehandel is 'n hoogs georganiseerde bedryf en funksioneer ondergronds ten einde nie onder die aandag van die owerhede te kom nie. Dit is dus moeilik om mensehandelaars vas te trek. Omdat mensehandel alle lande raak, behoort die voorkoming of verligting daarvan mettertyd wêreldwye prioriteit-aandag te geniet (Del Carmen Balderas, 2006:1).

\section{Oorsake van mensehandel}

Die volgende narratiewe van die deelnemers kan as verteenwoordigend van die standpunte oor die oorsake van mensehandel beskou word.

"Armoede en werkloosheid speel beslis 'n rol in mensehandel."

"They have the motive to become rich quickly without much effort."

Groot groepe immigrante, en veral onwettige immigrante, wat Suid-Afrika as 'n land van melk en heuning sien en dan ontnugter word, raak maklik by hierdie mensehandelnetwerke betrokke." 
Armoede, werkloosheid en die motief om vinnig ryk te word sonder om veel moeite te doen, is as die grootste oorsake van mensehandel onderskei (Loretz, 2004:18-19). Ontnugterde immigrante, en spesifiek onwettige immigrante, raak dikwels by mensehandel betrokke ten einde 'n inkomste in 'n vreemde land te bekom. Buitelanders behoort ingetrek te word by 'n land se algemene funksionering ten einde maatskaplike blootstelling, soos arbeidsuitbuiting, te verhoed of ten minste te beperk (Giammarinaro, 2011:1). Geldelike oorlewing blyk 'n belangrike veroorsakende faktor te wees om by mensehandel betrokke te raak. In 'n land met chroniese werkloosheid, wydverspreide armoede en 'n gebrek aan ekonomiese geleenthede maak mensehandelaars gebruik van valse beloftes van hoër lone en goeie werksomstandighede in vreemde lande (Loretz, 2004:18-19). Die alles oorheersende behoefte aan 'n beter lewe word dikwels verabsoluteer, wat meebring dat individue blind raak vir die realiteite wat met mensehandel gepaard gaan en magteloos staan teenoor die gevare van mensehandel (Lima, 2007:9; Loretz, 2004:18-19).

\section{Kenmerke van mensehandelaars}

Die volgende kan as die standpunte oor die kenmerke van mensehandelaars aangedui word.

"Die werwer is dikwels aan die persoon bekend of word doelbewuste pogings aangewend om die persoon van naby te leer ken."

"Mensehandelaars is dikwels buitelanders."

"Human traffickers often appear to be well dressed and pretend to be rich business men or business women in order to make themselves more appealing to the victim."

Uit hierdie enkele aanhalings blyk dit dus dat mensehandelaars doelbewus persone teiken en dan poog om hulle op die een of ander manier van nader te leer ken en sodoende by hul web in te trek. Mensehandelaars doen hulle dikwels voor as goedversorgde en welvarende sakemanne of -vroue, dikwels buitelanders, om die indruk te skep dat alles in orde is en sodat potensiële slagoffers nie agterdogtig raak nie.

\section{Werwing van slagoffers}

Met betrekking tot die werwing van slagoffers kan die volgende aangehaal word:

"Individue word'n algemene beter lewenskwaliteit aangebied."

"Mensehandelaars gebruik valse beloftes, bedrogskemas en soms selfs geweld om individue te werf."

"The person who recruits people, are promising them a nice job and a better future."

"Sodra mense vir hierdie beloftes geval het, word hulle vervoer, hetsy binne 'n land se grense of van een land na 'n ander."

"Persone wat desperaat vir werk of inkomste is, word maklik die prooi van mensehandelaars." 
"As persone hul bestemming bereik het, is daar geen omdraaikans vir die slagoffers nie en is hulle vasgevang in hulle situasie, waaruit hulle nie kan ontvlug nie."

"Slagoffers word nie net fisies gevange gehou nie, maar hulle het dikwels nie geld om vir vervoerkostes en alternatiewe verblyf te betaal nie."

Die werwing van slagoffers gaan gewoonlik gepaard met die aanwend van spesifieke metodes. Valse beloftes, soos 'n verbeterde lewensgehalte, is meestal die metode wat benut word om individue slagoffers van mensehandel te maak. Slagoffers word binne- of buitelands vervoer en as hulle besef wat werklik aan die gebeur is, beskik hulle ook nie oor die finansiële middele om na hul plek van oorsprong terug te keer nie en moet noodgedwonge, dikwels in aanhouding, daar aanbly. Loretz (2004:17-18) identifiseer vier werwingstrategieë om slagoffers oor te haal, naamlik deur 'n eksklusiewe werksaanbod in 'n eksotiese bestemming aan te bied, deur persone wat reeds by prostitusie betrokke is, te nader, deur mense te ontvoer of deur 'n arm gesin te nader om hul jong kinders te verkoop en dan 'n beter lewe elders vir hulle aan te bied.

\section{Die slagoffer}

In hierdie tema word die volgende twee sub-temas onderskei, naamlik die kenmerke van slagoffers en die impak van mensehandel op die slagoffer en die gesin.

\section{Kenmerke van slagoffers}

Oor die kenmerke van slagoffers het deelnemers die volgende te sê gehad.

"Some individuals, especially rural people, children and young adults are more vulnerable to be drawn into these cartels."

"Victims are mostly poor and struggling to survive on a day to day basis - they are thus more prone to be drawn into these schemes."

"The youth like money, because they are often lazy and don't want to workthey just need simple money for dressing up and having all the things that young people are perceived to have."

"Baie mense is op soek na 'n betrekking en swig dan voor hierdie valse beloftes van mensehandelaars."

"Mensehandelaars is meestal slinks, beskik oor goeie mensekennis en weet hoe om naïewe slagoffers te betrek."

"Beide mans en vroue is kwesbaar om 'n slagoffer van mensehandel te word, maar tog in die konteks van prostitusie sou vrouens waarskynlik meer as slagoffers uitgebuit word. In die geval van kinderarbeid en dwelmhandel sal seuns en mans waarskynlik meer as vroue gewerf word."

Slagoffers word dikwels gekenmerk deur naïwiteit en magteloosheid, en hulle beskik oor min onderhandelingsvaardighede. Dit is dikwels eers wanneer die persone by hul bestemming aanland dat hulle ervaar dat alles nie pluis is nie en hul in die web van mensehandelaars verval het (Lima, 2007:9). Hulle is dikwels mense wat hulle in 
moeilike finansiële en emosionele situasies bevind en is dikwels vroue of kinders. Die slagoffers van mensehandel word van hul basiese menslike waardigheid en vryheid gestroop en hulle vind hulle in gedwonge seksuele of arbeidsuitbuitende situasies vasgevang en kan kwalik aan bevrydingstrategieë dink om aan hierdie omstandighede te ontkom (Obama, 2010:1-3).

\section{Impak van mensehandel op die slagoffer en die gesin}

Aangaande die impak van mensehandel op die slagoffer en die gesin het deelnemers soos volg gereageer.

"It is hard to visualise the impact of this phenomenon on the physical and emotional aspects of the victim."

"It is not only the victim that is going to be affected, but everybody in the wider family circle."

"I think human trafficking is worse than even killing a person."

"Hoe kan die persoon ooit weer normaal teenoor ander mense optree?"

Mensehandel het 'n ingrypende impak op al die fasette van 'n individu se lewe. Nie alleen is daar ' $n$ fisiese impak op die individu nie, maar ook 'n geweldig emosionele en kognitiewe impak. Slagoffers verloor vertroue in mense; dus sal dit vir maatskaplike werkers moeilik wees om 'n verhouding met sodanige persone te kan opbou voordat daar van hulpverlening sprake kan wees. Die gesin en uitgebreide familie tree dikwels ook vreemd teenoor die slagoffer op en dié ervaar verwerping indien hulle na die gesin terugkeer, moontlik na maande of jare waarin hulle geen kontak met mekaar gehad het nie. Voor die persoon se vertrek was daar dalk al 'n swak verhouding wat in hierdie stadium net vererger het.

\section{Die taak van maatskaplike werk}

Onder hierdie tema word die volgende ses sub-temas onderskei, naamlik gemeenskapsopvoeding, multidissiplinêre samewerking, die prosedures wat in gevalle van mensehandel gevolg moet word, voldoende wetgewing, direkte maatskaplikewerkhulpverlening en navorsing.

\section{Gemeenskapsopvoeding}

Van die deelnemers wat alreeds by 'n bewusmakingsprojek betrokke was, het die volgende te sê gehad.

"The group could not believe what we had to say."

"Mensehandel is 'n realiteit en gemeenskappe behoort deeglik daarvan kennis te neem."

"Die gemeenskap dink steeds dat die verskynsel slegs in ander lande en met ander mense gebeur."

"Skole en sekere kwesbare gemeenskappe behoort veral geteiken te word vir bewusmakingsveldtogte." 
"Gemeenskapsopvoeding is die taak van die maatskaplike werker en behoort sodanige projekte gekoördineerd aangebied te word."

Die gemeenskap beskou mensehandel nog nie as 'n realiteit nie, en sommige persone het nog nooit hiervan te hore gekom nie. Die gemeenskap reageer meestal met verbasing met die aanhoor van die verskynsel en beskou dit as iets wat hulle nie raak nie. Skole en veral uitgelewerde gemeenskappe behoort geteiken te word met die oog op bewusmaking en opvoeding. Geen bewusmakingsveldtog kan doeltreffend wees as dit nie geteiken word op spesifieke, identifiseerbare gehore nie, as geen optrede van die betrokkenes gevra word nie en as die resultate van die veldtog nie geëvalueer word nie (United Nations Educational, Scientific and Cultural Organization, 2007:59-60). Gemeenskapsopvoeding, die uitbreiding van geleenthede, die bevordering van toegang tot formele opleiding vir alle mense op alle vlakke en werkskepping is van die uiterste belang ter voorkoming van mensehandel (United Nations Educational, Scientific and Cultural Organization, 2007:59-60). Kultureel sensitiewe en kreatiewe maniere om gemeenskappe by gemeenskapsopvoedingsprogramme te betrek, moet voortdurend in ag geneem word (Loretz, 2004:6).

\section{Multidissiplinêre samewerking}

Betreffende multidissiplinêre samewerking tussen die verskillende rolspelers kan die volgende opmerkings as verteenwoordigend van die verskillende standpunte beskou word:

"Ons as maatskaplike werkers het nie genoeg tyd en kennis om die probleem alleen aan te pak nie."

"Human trafficking is a phenomenon to be treated with proper knowledge, skills and techniques by all applicable professionals."

"We lose focus of what a social worker should really do and tend to focus on less important things - human trafficking is becoming a real challenge for social work."

Maatskaplike werkers kan as een van die belangrikste rolspelers in die hantering van mensehandel beskou word, en dit is dikwels die eerste persoon met wie 'n slagoffer in aanraking sal kom. Maatskaplike werkers kan dien as veranderingsagente vir slagoffers van mensehandel, omdat hulle slagoffers kan bystaan en help om ondersteuningsdienste te bekom (Loretz, 2004:5). Die doel van maatskaplike werk as 'n professie is om te beskerm, as voorspraak op te tree, maatskaplike geregtigheid te bevorder en uitgelewerde gemeenskappe te bemagtig. Maatskaplike werkers moet die verskynsel "mensehandel" ken en weet dat die huidige benaderings nie noodwendig hierdie probleem na behore onder die loep neem nie (Michael, 2000:3).

Wanneer 'n slagoffer van mensehandel geïdentifiseer is, moet maatskaplike werkers, indien nodig, gepaste verwysings maak na organisasies wat op ondersteuning vir hierdie slagoffers fokus. Mensehandel is egter nie die uitsluitlike terrein van maatskaplike werk nie en multidissiplinêre samewerking behoort gereeld plaas te vind. Dit is van kardinale belang dat hulpverleners presies moet weet wat om in mensehandel-situasies te doen en 
watter aspekte prioriteit-aandag moet geniet. Dit is dus nodig om 'n duidelike roluiteensetting vir die verskillende hulpverleners te gee en strategieë dienooreenkomstig uit te werk.

Die span behoort behoorlik opgelei te word ten opsigte van "mensehandel" en wat elke rolspeler se taak met betrekking tot die hantering van die probleem behoort te wees. As gevolg van die gebrek aan kennis by die relevante rolspelers en die onsekerheid waarin die verskynsel gehul is, word gevalle van mensehandel dikwels as ontvoering en prostitusie geklassifiseer, en nie as mensehandel nie. Dit kan ook die rede wees vir die gebrek aan betroubare statistiek om die verskynsel in Suid-Afrika na behore te kan omskryf.

Volgens Michael (2000:14-15) is daar verskillende struikelblokke en uitdagings waardeur die verskillende rolspelers in die gesig gestaar word as dit kom by die bystand van die slagoffer. Maatskaplike werkers en ander betrokkenes moet intensiewe opleiding oor mensehandel ontvang, ook wat mishandeling op die verskillende vlakke behels, soos die fisiese, verstandelike, seksuele, sosiale, geregtelike en psigologiese vlakke (United Nations Educational, Scientific and Cultural Organization, 2007:59-60). Taal- en kultuurverskille behoort ook in sodanige opleiding aandag te geniet, sowel as die prosedures vir die hantering van sodanige gevalle.

Werkswinkels, gespreksgeleenthede en konferensies behoort die spesifieke rol met betrekking tot mensehandel aan alle betrokkenes oor te dra. Benewens die verskillende professionele rolspelers behoort die Suid-Afrikaanse Polisiediens en die Departement van Binnelandse Sake 'n belangrike bydrae te lewer met betrekking tot mensehandel.

\section{Prosedures om in gevalle van mensehandel te volg}

Die volgende opmerkings is deur deelnemers gemaak met betrekking tot die prosedures om ingeval van mensehandel te volg.

"Na aanmelding behoort die veiligheid van die slagoffer die eerste prioriteit te wees."

"Indien nodig moet 'n deeglike mediese ondersoek plaasvind."

"Die verskillende rolspelers moet mekaar aanvul in die behandeling van die persoon."

"The issue of interpretation can be a really frustrating situation that can cause misunderstanding and even harm to the victim in certain circumstances."

"Onnodige en uitmergelende ondervraging van slagoffers moet so ver moontlik vermy word."

Alle professionele en nie-professionele persone wat by mensehandel betrokke is, benodig ' $n$ spesifieke protokol en prosedures om die fenomeen te hanteer (Loretz, 2004:3). Al die deelnemers aan die ondersoek is dit eens dat die fisiese veiligheid van die slagoffer verseker moet word, waarna hy/sy ingelig moet word dat die aangeleentheid vertroulik hanteer sal word en dat menswaardigheid deurgaans gerespekteer sal word. Indien nodig moet die slagoffer 'n omvattende mediese ondersoek 
ondergaan ten einde enige fisiese letsels te kan bepaal, waarna die persoon in 'n Plek van Veiligheid of krisis-sentrum geplaas behoort te word (International Organisation for Migration, 2009b:82-83). Dit is ook so dat daar nie in alle gemeenskappe voldoende veiligheids- en ander hulpbronne beskikbaar is nie. Hierna behoort verdere hulpbronne betrek te word, soos die ouers, voogde, vriende en moontlik 'n kerk- of geloofsverband.

Die gebruik van tolke word dikwels benodig in gevalle van mensehandel. Met tolking gaan daar dikwels belangrike inligting verlore en veroorsaak dit ook onnodige spanning vir die slagoffer en kan die verhouding tussen die slagoffer en die maatskaplike werker ook benadeel word. Langdurige en onnodige uitvraging moet sover moontlik vermy word ten einde slagoffers verdere trauma te spaar. Die nodige inligting moet dus op ' $\mathrm{n}$ sensitiewe wyse van die slagoffer verkry word ten einde die beste hulpverlening te kan bied.

\section{Voldoende wetgewing}

Die volgende opmerkings van deelnemers kan as verteenwoordigend beskou word van die standpunte rakende wetgewing oor mensehandel.

"Daar bestaan nie voldoende beskermingsmaatreëls en wetgewing vir mensehandel in Suid-Afrika nie."

"Really, human trafficking has been existing for so long, but no substantial legislation exists."

"In mensehandel word tans nog te veel klem op die kriminele aspek gelê en nie gefokus op die slagoffers wat relatief onskuldig in die slagyster beland het nie."

"Volgens my bestaan daar voldoende wetgewing, maar professionele persone weet nie altyd hoe om dit te implementeer nie."

"If a child has been trafficked, he/she is in need of care and protection. The new

Child Care Act is all about the care and protection of children."

Van die deelnemers huldig die standpunt dat daar nie voldoende en toepaslike wetgewing bestaan rakende mensehandel nie. Ander meen weer dat daar voldoende wetgewing bestaan, en spesifiek die Kinderwet, wat tog in die geheel oor versorging en beskerming handel. Daar is selfs 'n spesifieke hoofstuk oor mensehandel in die Kinderwet, Wet 38 van 2005. Maatskaplike werkers moet deeglik op hoogte wees van alle toepaslike wetgewing aangaande hierdie probleem (Loretz, 2004:5) en waar leemtes wel voorkom, sorg dat dit in wetgewing ondervang word.

\section{Direkte maatskaplikewerk-hulpverlening}

Die volgende is deur deelnemers oor direkte hulpverlening opgemerk.

"Slagoffers van mensehandel het intensiewe maatskaplikewerk-hulpverlening nodig."

"Waar diep intrapsigiese trauma teenwoordig is, behoort verwysings na sielkundiges of psigiaters gedoen te word." 
"Aangesien maatskaplike werkers dikwels die eerste linie van aanmelding vorm, behoort hul te weet wanneer en hoe om slagoffers vir meer gespesialiseerde hulp te verwys."

"As a social worker you will be able to identify that a particular victim of human trafficking is not coping with what happened to him or her."

"By not getting the needed help, the victim can easily become the victim of the situation."

Maatskaplikewerk-hulpverlening vorm dikwels die eerste linie van aanmelding en hulpverlening en behoort op 'n intensiewe gevallewerk-basis plaas te vind. Maatskaplike werkers behoort te besef dat indien daar intrapsigiese probleme, soos angsversteurings en paranoia, by kliënte teenwoordig is die kliënt na 'n sielkundige of psigiater verwys moet word. Maatskaplike werkers sal egter die tekens by kliënte moet kan herken en kan identifiseer ten einde hulle na verdere gespesialiseerde hulpverlening te kan verwys. Slagoffers word dikwels van een persoon na 'n ander verwys wat uiters frustrerend kan wees en vertroue in hulpverleners ondermyn. Doeltreffende hulpverlening versnel die herstelproses en ontwikkel 'n sterk gevoel van bemagtiging te wees (Michael, 2001:415).

\section{Navorsing}

Oor navorsing in verband met mensehandel het deelnemers die volgende standpunte gelug:

"We need to educate ourselves on human trafficking, gain all the information available and do more research."

"Baie min wetenskaplike geskrifte bestaan oor mensehandel en behoort die gaping met toepaslike navorsing gevul te word."

"Navorsing behoort nie net oor die verskynsel van mensehandel gedoen te word nie, maar beslis ook oor die rol van maatskaplike werk in die hulpverlening aan die slagoffers van mensehandel."

"Nuut ingesamelde feite moet gepubliseer word ten einde die verspreiding van die data te kan bewerkstellig."

Mensehandel is nie 'n nuwe verskynsel nie, maar die kompleksiteit van die verskynsel het in die afgelope 15 jaar geweldig toegeneem (Salett, 2006:1). Hulpverleners het die jongste kennis oor mensehandel nodig en meer wetenskaplike navorsing is dringend noodsaaklik. Die bydrae wat maatskaplike werk tot die voorkoming of verligting van mensehandel kan lewer, is veral van kardinale belang. Daar bestaan 'n behoefte aan vergelykende studies tussen lande en om internasionale samewerking tussen maatskaplike werkers met betrekking tot mensehandel te bevorder (Zierer, 2011:1). Hierdie navorsingsresultate moet dan onder maatskaplike werkers versprei word sodat die jongste inligting oor die verskynsel van mensehandel algemeen vrylik beskikbaar kan word. 


\section{BESPREKING VAN BEVINDINGE}

Uit bogenoemde resultate het daar verskillende temas en sub-temas na vore getree. Literatuurkontrole kon ook in die meeste gevalle gedoen word. Tema 1 handel oor mensehandel en die mensehandelaar. Vier sub-temas is hier onderskei waarvan die begrip "mensehandel" eerstens ter sprake gekom het. Die deelnemers aan die ondersoek se response het ooreengestem met die bestaande omskrywings van "mensehandel" en het selfs bygedra tot die uitbouing van die definisie daarvan.

Die oorsake van mensehandel is as tweede sub-tema onderskei. Armoede, werkloosheid en die motief om vinnig ryk te word sonder om veel pogings daartoe aan te wend is as die grootste oorsake van mensehandel bespreek. Onwettige immigrante wat na SuidAfrika gekom het met vooruitsigte van vinnige rykdom en dan ontnugter raak as gevolg van 'n gebrek aan ekonomiese geleenthede, raak dikwels by mensehandel betrokke.

Die kenmerke van mensehandel is as derde sub-tema onderskei. Mensehandelaars doen hulle dikwels voor as welgestelde sakemanne wat sekere persone doelbewus teiken en hulle dan mettertyd van nader leer ken en geleidelik by hul netwerke intrek. As vierde sub-tema is die werwing van slagoffers onderskei en word die aanwending van spesifieke metodes, soos valse beloftes van goeie vooruitsigte van 'n buitelandse reis of vinnige rykdom ingespan om naïewe fortuinsoekers by hul skemas te betrek.

Tema 2 handel oor die slagoffer van mensehandel en hierdie tema word in twee subtemas verdeel. Die kenmerke van slagoffers word as die eerste sub-tema behandel. Die profiel van slagoffers word dikwels deur naïwiteit, magteloosheid en 'n gebrek aan onderhandelingsvaardighede gekenmerk. Slagoffers is dikwels vroue of kinders wat hulle in moeilike finansiële omstandighede bevind en wat kwalik aan bevrydingstrategieë kan dink om aan hierdie omstandighede te ontkom. Die impak van mensehandel op die slagoffer en die gesin word as die tweede sub-tema onderskei. Mensehandel raak die individu en die gesin op alle lewensvlakke en vertrouensbreuke vind plaas wat moeilik herstel kan word. Die individu verloor dikwels vriende, en die verhouding met die gesin, familie en gemeenskap word ernstig benadeel.

Tema 3 verdiskonteer die taak van die maatskaplike werker en word in ses sub-temas behandel. Die eerste sub-tema handel oor gemeenskapsopvoeding wat geteiken behoort te word op spesifieke gehore soos skole en uitgelewerde gemeenskappe. Bewusmakingsveldtogte moet op kultuur sensitiewe en kreatiewe maniere geskied ten einde persone nie met 'n magdom inligting te oorweldig nie, maar juis om die korrekte inligting deur te gee.

Multidissiplinêre samewerking word as die tweede sub-tema in hierdie kategorie onderskei. Maatskaplike werkers kan as een van die belangrikste rolspelers in die hantering van gevalle van mensehandel beskou word juis omdat hulle dikwels die eerstes is met wie hulle in aanraking sal kom. Die taak van maatskaplike werk is juis om persone te beskerm, geregtigheid te bevorder en uitgelewerde gemeenskappe te bemagtig. Die maatskaplike werker is egter nie die uitsluitlike eienaar ter bekamping van die verskynsel nie en behoort deeglik te weet hoe en waarheen om persone te 
verwys, hetsy vir mediese of psigologiese aandag of om mense in verbinding te stel met die Suid-Afrikaanse Polisiediens of die Departement van Binnelandse Sake.

Die prosedures om te volg in gevalle van mensehandel word as die derde sub-tema onderskei. 'n Spesifieke protokol en prosedures behoort tot beskikking van alle hulpverleners te wees ten einde die vinnigste en korrekste diens aan slagoffers te kan verskaf. Die slagoffer moet rustig en met respek hanteer word ten einde menswaardigheid ten alle tye te handhaaf. Dit is belangrik om aan die persoon 'n gevoel van veiligheid te gee, weg van die bedreiging. Eers as daar aan die basiese behoeftes van die slagoffer aandag geskenk is, behoort al die ander hulpbronne betrek te word soos die ouers, voogde en vriende. Die proses sal nie noodwendig in 'n bepaalde volgorde verloop nie en soms sal ander rolspelers soos die ouers of predikant eerste betrek word, of selfs die probleem aanmeld.

Voldoende wetgewing word as sub-tema vier hanteer. Wetgewing oor mensehandel kan verder uitgebrei word, maar dit sal ook reeds help as bestaande wetgewing, soos die Kinderwet, deeglik bestudeer en toegepas word. Persone wat spesifiek met wetgewing gemoeid is, behoort aandag te skenk aan die verdere formulering van uitbreidings op bestaande wetgewing ten einde mensehandel volledig die hoof te kan bied namate die verskynsel verder ontplooi.

Direkte maatskaplikewerk-hulpverlening word as sub-tema vyf aangebied. Maatskaplike werkers moet deeglik besef wat hulle taak in gevalle van mensehandel is en wanneer hulle na meer gespesialiseerde dienste behoort te verwys. Dit is egter belangrik dat slagoffers van mensehandel nie van bakboord na stuurboord gestuur moet word nie, maar wel die doeltreffendste diens binne die kortste tydperk moet ontvang.

Navorsing word as sub-tema ses behandel en behoort daarop te fokus om die kennisbasis van maatskaplike werk oor mensehandel en die taak van die maatskaplike werker uit te brei en aktueel te hou ten einde tred te kan hou met 'n hoogs dinamiese verskynsel. Relevante navorsing oor mensehandel moet op 'n doeltreffende wyse onder maatskaplike werkers en ander partye versprei word.

\section{AANBEVELINGS}

- Gemeenskapsopvoeding moet aandag op alle vlakke geniet, veral gefokus op skole en uitgelewerde gemeenskappe. Gemeenskapsontwikkelingsprojekte kan baie vermag ten einde die verskynsel op 'n voorkomende vlak aan te pak.

- Maatskaplike werkers en alle rolspelers in die hantering van mensehandel moet volledig opgelei word ten einde die verskynsel doeltreffend te kan bekamp.

- Die benutting van en koördinering tussen die lede van die multidissiplinêre span moet wel deeglik aandag geniet.

- 'n Vennootskapsverhouding tussen die lede van die span moet tot stand kom ten einde die beste diens aan slagoffers te kan lewer.

- Riglyne moet ontwikkel word wat die prosedures beskryf waarvolgens gevalle van mensehandel hanteer behoort te word. 
- Meer relevante navorsing op hierdie gebied behoort aandag te geniet. Navorsing behoort nie alleen op die omvang van die probleem te fokus nie, maar ook op voorkomingsmaatreëls en gepaste intervensies.

Aandag behoort geskenk te word aan gekonsolideerde wetgewing oor mensehandel wat al die aspekte daarvan dek soos ontvoering, dwelmhandel, gedwonge arbeid, prostitusie en handeldryf met organe.

\section{SAMEVATTING}

Met die onderneem van die ondersoek het die navorser die kennis en persepsies van maatskaplike werkers van verskeie organisasies ingewin, ten einde vas te stel wat maatskaplike werkers se sienings is van hul rol by mensehandel en hoe hulle meen hulle 'n bydrae tot die afname in hierdie vorm van misdaad kan lewer. Die vrae wat aan die respondente gestel is, het die struikelblokke wat hulle ondervind, uitgewys, asook wat hulle meen die belangrikste take van die maatskaplike werker is om die doeltreffendste hulp aan slagoffers van mensehandel te kan bied.

Mensehandel is een van die wreedste misdade wat gepleeg word, en slagoffers van hierdie misdaad word deur uiterste wreedhede in die gesig gestaar. Mensehandel is 'n realiteit, en maatskaplike werk behoort ' $\mathrm{n}$ belangrike rol by die bekamping van mensehandel te speel. Maatskaplike werkers dien as veranderingsagente in die lewens van slagoffers van mensehandel, juis omdat hulle hierdie slagoffers ondersteun en van hulp voorsien. Dit is duidelik dat daar meer samewerking behoort te wees tussen al die partye wat met die bekamping van mensehandel gemoeid is.

\section{BIBLIOGRAFIE}

ADULT AND FAMILY SERVICES. s.a. [Online] Available: http://www.appogg. gov.mt/adultand family_humantrafficking.asp. [Accessed: 19/09/2011].

BABBIE, E. \& MOUTON, J. 2010. The practice of social research. Cape Town: Oxford University Press.

BLUM, L. 2008. Sex trafficking and political discourse: a case study of the perceptions and definition of the problem and its victims in Moldova. Arkansas: University of Arkansas. (DPhil Thesis)

CORBY, B. 2006. Applying research in social work practice. New York: Open University Press.

DEL CARMEN BALDERAS, M. 2006. Human trafficking: a comparative analysis of the perceptions of college students and police officers. Arlington: University of Texas. (MA Thesis)

DE VOS, A.S., STRYDOM, H., FOUCHÉ, C.B. \& DELPORT, C.S.L. 2011. Research at grass roots: for the social sciences and human service professions. Pretoria: Van Schaik Publishers. 
DE VOS, A.S., STRYDOM, H., FOUCHÉ, C.B., POGGENPOEL, M. \& SCHURINK, W. 1998. Research at grass roots: a primer for the caring professions. Pretoria: Van Schaik Publishers.

DUNN, K. 2003. Human trafficking: children or commodity? International and domestic child sex trafficking. Kansas: University of Kansas. (MA Thesis)

ENGEL, R.J. \& SCHUTT, R.K. 2010. Fundamentals of social work research. Los Angeles: Sage Publications.

GIAMMARINARO, M.G. 2011. Social inclusion of migrant workers critical to preventing human trafficking. [Online] Available: http://www.osce.org/cthb/81634. [Accessed: 20/09/2011].

GRINNELL, R.M. \& UNRAU, Y.A. 2008. Social work research and evaluation: foundations of evidence-based practice. New York: Oxford University Press.

INTERNATIONAL ORGANIZATION FOR MIGRATION (IOM). 2005. Data and research on human trafficking: a global survey. Special offprint of International Migration, 43(1-2).

INTERNATIONAL ORGANIZATION FOR MIGRATION (IOM). 2009a. Trafficking in persons: not just a cross-border problem. Eye on Human Trafficking, 20:1-8.

INTERNATIONAL ORGANIZATION FOR MIGRATION (IOM). 2009b. Caring for trafficked persons: guidance for health providers. [Online] Available: http://www.rescue.org/our-work/anti-trafficking-initiative. [Accessed: 20/09/2011].

INTERNATIONAL RESCUE COMMITTEE. 2003. Fighting human trafficking. [Online] Available: http://www.rescue.org/our-work/anti-trafficking-initiative. [Accessed: 20/09/2011].

JOSHI, A. 2002. The face of human trafficking. Hastings Women's Law Journal, 13(1):18-40.

LIMA, B.M. 2007. Services for women and children survivors of human trafficking. A grant proposal project. Long Beach: California State University. (MA Thesis)

LORETZ, N. 2004. Human trafficking: Identification, education and awareness. A grant proposal. Long Beach: California State University. (MA Thesis)

MICHAEL, A. 2000. A qualitative study of the experiences of service providers who work with victims of human trafficking. Long Beach: California State University. (MA Thesis)

MITCHELL, M.L. \& JOLLEY, J.M. 2010. Research design explained. New York: Wadsworth Cengage Learning.

MONETTE, D.R., SULLIVAN, T.J. \& DEJONG, C.R. 2011. Applied social research: a tool for the human services. New York: Brooks/Cole Cengage Learning. 
OBAMA, B.H. 2010. Proclamation 8471 - National Slavery and Human Trafficking Prevention Month, 2010. Washington D.C.: Daily Compilation of Presidential Documents.

SALETT, E.P. 2006. Human trafficking and modern-day slavery. Washington: NASW Press.

THYER, B. 2010. The handbook of social work research methods. Los Angeles: Sage Publications.

UNITED NATIONS EDUCATIONAL, SCIENTIFIC AND CULTURAL ORGANIZATION (UNESCO). 2007. Human trafficking in South Africa: root causes and recommendations. Policy paper, 14.5:1-70.

ZIERER, B. 2011. Comparative social work and trafficking in women. [Online] Available: http://www.socmag.net/?p=175. [Accessed: 19/09/2011].

Me Yolanda Mynhardt, maatskaplike werker, Jakaranda Kinderhuis, East Lynne, Pretoria; Prof Herman Strydom, Vakhoof vir Maatskaplike Werk, NoordwesUniversiteit (Potchefstroomkampus), Potchefstroom, Suid-Afrika. 